\title{
FORUM
}

Submitted 12.09.2013. Approved 09.10.2014

Evaluated by double blind review process. Scientific Editors: Edgard Barki, Graziella Comini, Ann L Cunliffe, Stuart Hart and Sudhanshu Rai

DOI: http://dx.doi.org/10.1590/So034-759020150405

\section{CAUSE-FIT, POSITIVE ATTITUDES AND BEHAVIORS WITHIN HYBRID COLOMBIAN ORGANIZATIONS}

\author{
Adesão à causa, atitudes e comportamentos positivos nas organizações híbridas \\ colombianas \\ Adhesión a la causa, actitudes y comportamientos positivos en organizaciones \\ híbridas colombianas
}

\begin{abstract}
Socially oriented ventures have provided livelihoods and social recognition to disadvantaged communities in different corners of the world. In some cases, these ventures are the result of Corporate Social Responsibility (CSR) programs. In Latin America, this type of undertaking has responded positively to unmet social needs. The social cause drives these organizations and their human resources and they give high value to organizational cause-fit. This paper presents empirical evidence of the effects of perceived cause-fit on several worker attitudes and behaviors. Psychological contract theory was adopted as theoretical background. Employees working in a hybrid (for-profit/socially oriented) Colombian organization created by a CSR program participated in the survey. Data provided by 218 employees were analyzed using PLS structural equation modeling. The results suggest the ideological components of the employee-employer relationship predict positive attitudes and cooperative organizational behaviors towards hybrid organizations.
\end{abstract}

KEYWORDS | Hybrid organizations, Corporate Social Responsibility, social cause, cooperative behaviors, social entrepreneurship.

\section{RESUMO}

Empreendimentos orientados ao social fornecem sustento e reconhecimento social para comunidades desfavorecidas em diferentes partes do mundo. Em alguns casos, estes empreendimentos são o resultado de programas de Responsabilidade social empresarial (RSE). Na América Latina este tipo de empreendimento tem respondido positivamente às necessidades sociais. A causa social dirige essas organizações e seus recursos humanos, e valoriza a adesão à causa organizacional. $O$ artigo apresenta uma evidência empírica em relação aos efeitos percebidos de adesão à causa sobre as atitudes e comportamentos dos trabalhadores. 0 estudo foi baseado na teoria do contrato psicológico. Empregados de uma empresa colombiana híbrida (fins lucrativos/orientação social) criada a partir de uma iniciativa da RSE participaram da investigação. Os dados foram analisados através da modelação por equações estruturais (PLS). Os resultados indicam que os componentes ideológicos da relação empregado-empregador tem atitudes positivas e comportamentos cooperativos paras as organizações híbridas.

JUAN PABLO ROMÁN-CALDERÓN jromanca@eafit.edu.co

Professor at Universidad Eafit, Departamento de Organización y Gerencia - Medellín, Colombia

\section{CARLO ODOARD}

carlo.odoardi@unifi.it Professor at Università Degli Studi Firenze, Dipartimento di Scienze Formazione e Psicologia - Firenze, Italy

\section{ADALGISA BATTISTELLI}

adalgisa.battistelli@u-bordeaux.fr Professor at Université de Bordeaux, Laboratoire de Psychologie Bordeaux, France
PALAVRAS-CHAVE I Organizações híbridas, Responsabilidade Social Empresarial, missão social, comportamentos colaborativos, empreendedorismo social.

\section{RESUMEN}

Las empresas orientadas hacia lo social proveen reconocimiento social y sustento para comunidades en situación de desventaja. En algunos casos, estas empresas son el resultado de programas de Responsabilidad Social Empresarial (RSE). En América Latina, este tipo de emprendimiento ha respondido positivamente a necesidades sociales. Los recursos humanos de dichas empresas están altamente motivados por la misión social de la organización y le dan mucho valor al grado en el cual la empresa se ajusta a esta. El presente artículo presenta una investigación empírica acerca del ajuste de dichas organizaciones a su misión social y el efecto que este tiene sobre las actitudes y comportamientos de los trabajadores. El estudio se basó en la teoría del contrato psicológico. Los empleados de una empresa colombiana híbrida (ánimo de lucro/ orientación social) creada a partir de una iniciativa de RSE participaron en la investigación. Los datos fueron analizados a través de la modelación por ecuaciones estructurales (PLS). Los resultados indican que el ajuste de las organizaciones híbridas a su misión social tiene efectos positivos sobre la satisfacción de los trabajadores y sobre comportamientos colaborativos hacia la empresa.

PALABRAS CLAVE I Organizaciones híbridas, Responsabilidad Social Empresarial, misión social, comportamientos colaborativos, emprendimiento social. 


\section{INTRODUCTION}

Inequity, social needs and economic development affect the lives of millions of human beings in Latin America. According to World Bank data, Colombia has been paradigmatic with regard to socio-economic inequality. With a GINI index reaching 50 points over the last 5 years, an index of 100 points meaning perfect inequality, Colombia is still among the more unequal countries worldwide. In face of this, a number of initiatives to alleviate social and economic disparity are taking place in Colombia. New public and private ventures directed to enhance socio-economic wellbeing and the strengthening of existing socially oriented ventures are shaping the Colombian socio-economic landscape positively. In developing countries, Corporate Social Responsibility (CSR) programs have different organizational outcomes (Jamali \& Mirshak, 2007). Originated by Corporate Social Responsibility (CSR) programs, many of these social undertakings intend to be independent organizations and have a dual/hybrid nature. Hybrid organizations have a double mission (Austin, Stevenson, \& Wei-Skillern, 2006). On the one hand, they pursue economic sustainability. On the other hand, they have a salient social mission (Levi \& Davis, 2008). The social mission of a hybrid organization can be defined as "an organizational commitment to address human needs that are unmet by state and markets providers or arise because of their efforts to satisfy other needs" (Doherty, Foster, Mason, Meehan, Rotheroe, \& Royce, 2009). Research on hybrid organizations in Colombia is important given that this type of organization can help to tackle social issues such as the violence and socioeconomic inequality that have characterized the country for years.

Hybrid organizations created by CSR programs have a declared social orientation. Furthermore, people working in these socially oriented ventures have a specific value orientation. Socially oriented organizations with good corporate social performance attract people to whom the values and norms expressed by corporate social responsibility actions have special meaning (Greening \& Turban, 2000). According to Bhattacharya, Sen, and Korschun (2008) some individuals want to align themselves to the organization's social values and commitments. Recently, Michailides and Lipsett (2013) investigated frontline employee attitudes towards CSR. In their study, they did not find significant evidence of the relationship between organizational climate, educational level and CSR worker orientations (Michailides \& Lipsett, 2013). In their view, these findings may be explained by "the effectiveness of CSR communications at stimulating some degree of alignment of individual values to corporate purpose" (Michailides \& Lipsett, 2013, p. 313). The authors of this paper contend there may be other individual variables exerting an important influence on the positive relationship between worker values and organi- zational goals. Specifically, they posit that much of the workers alignment with the organizational social values depends on the perceptions, interests and ideological orientations of the individuals. Furthermore, several scholars suggest that this alignment would have a positive effect on other worker attitudes and behaviors such as organizational commitment and intentions to leave (Bhattacharya et al., 2008; Chong, 2009). Bhattacharya et al. (2008) research results suggest that employee commitment to the corporate social responsibility (CSR) program led to pro-company citizenship behaviors and feelings of pride, which in turn positively related to employee performance and negatively to intentions to quit. These authors suggest that company characteristics such as cause-fit may lead to worker identification, increased job satisfaction and commitment to continue employment (Bhattacharya et al., 2008). However, more needs to be done to identify the psychological mechanisms through which:

- Employees of hybrid enterprises coming from CSR programs align to the organizational socially oriented values and norms.

- This psychological/ideological bond boosts positive attitudes and behaviors directed to these organizations.

This paper presents an empirical research that intended to disentangle some of the psychological mechanisms explaining these relationships. In particular, the study inquired if perceived cause-fit had positive effects on the worker's social identification with the organization, job satisfaction and cooperative behaviors towards the organization. In order to validate this set of theoretical assertions simultaneously, empirical data collected in a Colombian socially oriented enterprise were analyzed using second-generation statistical techniques. This hybrid organization was created by a for-profit organization in order to cope with high local unemployment rates. Both organizations lead the regional textile sector. They produce and commercialize underwear, respectively. One of the top executives of the for-profit organization created the hybrid organization. His leit-motif was to help a group of disadvantaged women in his hometown by creating a new economic activity. Following successful experiences in the region, he gathered public and private resources to create an enterprise deemed to be managed and owned by the employees. Women affected by political violence were the targets of the CSR program. Right from the beginning, the business has been fully independent from the parent organization. Almost 30 years of activities animating the regional economic landscape and integrating local women to the economic and social life, have granted this hybrid organization the acknowledgement of locals, and the right of being used by other hybrid Colombian enterprises as a model. Furthermore, the organization 
is considered a good place to work, inside and outside the walls. Largely, these perceptions seem to be the result of the organization's commitment to the social mission. In particular, this research studied the perceptions related to the organizational commitment to the social mission. More specifically, the results of this study provide further empirical results to Bhattacharya et al. (2008, p. 38) assertion according to which "the specificity with which a company supports or engages in a social initiative makes a big difference to how it is perceived by employees".

\section{IDEOLOGICAL OBLIGATIONS, RESPECT AND COOPERATIVE BEHAVIORS DIRECTED TO THE ORGANIZATION}

Prior research in socially oriented enterprises has demonstrated that non-monetary remunerations are key in order to improve worker compensation (Amin, 2009; Mosca, Musella, \& Pastore, 2007). Because people working in these enterprises care about non-monetary compensations, some researchers argue that people working in non-profits are characterized by a specific ideological profile (Borzaga \& Bacchiega, 2001). Despite empirical evidence showing that people working in different sectors care about non-monetary compensations, virtually no research has inquired the ideological profile in terms of employee attachment to the goals of organizations resulting from CSR programs. As suggested before, worker alignment with the values represented by CSR programs would depend on organizational characteristics such as perceived cause-fit. Psychological contract theory can help to shared light on how workers' perceived cause-fit modify their attitudes and positive behaviors towards the organization.

Theory and research on the employer-employee exchange suggest that the psychological contract (PC) approach is suitable to study employment relationships based on ideological grounds. PCs are unwritten arrangements based on the belief of reciprocal obligations (Rousseau, 1989, 1995). These obligations are different in nature. According to Rousseau (2001), and Thompson and Bunderson (2003), along with economic and emotional contents, the employee-employee exchange is shaped by ideological terms. Ideological contents are employer and employee perceived reciprocal obligations with respect to the social cause of the organization (Bingham, 2005). These ideological psychological obligations compose the ideological psychological contract (IPC). Up to date, the ideological terms of the PC have been studied in the for-profit, nonprofit, health care and educational organizations (Bal \& Vink, 2011; Bingham, 2005; Thompson \& Bunderson, 2003). The IPC construct has demonstrated predictive validity in both the for-profit and non- profit sectors (Bingham, 2005; Vantilborgh et al., 2013). Arguably, the IPC construct is suitable to study the effects of the links between ideological obligations within hybrid organizations in terms of positive attitudes and behaviors directed to the organization.

Organizational citizenship behavior (OCB) studies have a long-standing tradition (Dalal, 2005). The OCB construct refers to off-role behaviors highly related to cooperation (Smith, Organ, \& Near, 1983). From the point of view of their consequences, OCBs encompass "contributions to the maintenance and enhancement of the social and psychological context that support task performance" (Organ, 1997, p. 91). OCBs directed to co-workers (OCBI) and those directed to the organization (OCBO) should be distinguished (McNeely \& Meglino, 1994; Organ, 1997; Williams \& Anderson, 1991). OCB's antecedents have been profusely studied. Williams and Anderson (1991) found that job satisfaction was an important antecedent of OCBs (Williams \& Anderson, 1991). Further, according to Tyler and Blader (2002), cooperative behaviors on behalf of the organization are likely to occur when workers feel the organization respects them. Recently, Boezeman and Ellemers (2007) studied the influence of workers' feelings of respect by the organization on cooperative behaviors directed to the organization. Respect refers to the assessment that one is accepted as a member of the organization (Tyler \& Blader, 2002). This assessment is one of the processes through which the employee's social identification process is consolidated with the organization. Thus, the more respected the employee feels, the more he or she identifies with the organization. Using intentions to remain in the organization as a proxy variable, Boezeman and Ellemers (2007) found that organizational respect had an indirect and positive influence on cooperative behaviors directed to the organization in a sample of volunteers (Boezeman \& Ellemers, 2007). Boezeman and Ellemers' (2007) results indicate that the influence of respect on intentions to remain is mediated by organizational commitment. However, positive organizational behaviors directed to the organization widely overcome the intentions to remain. The authors of this paper posit that in hybrid organizations the effect of respect on a wider array of cooperative behaviors (i.e. OCBs directed to the organization and turn over intentions) would be mediated by job satisfaction. Given the social orientation of hybrid organizations and the fact that people related to them are attracted by such orientation, the more identified (i.e. respected) with the organization, the more satisfied the employee is with his (her) job. In turn, within these organizations, respect would mediate the effect of ideological obligations on job satisfaction. People perceiving organizational ideological obligations would feel obligated to accomplish the organizational social goal, identified with the organization, and satisfied with their job. Prior studies on the effects of PCs indicate that job dissatisfaction mediates the effect of psychological contract violations on 
several organizational outcomes (Turnley \& Feldman, 2000). Further empirical evidence demonstrates that IPC content also predicts job satisfaction. Bingham (2005) found a significant relationship between fulfillment of the IPC and job satisfaction. However, no research has investigated the mediating variables intervening in the relationship between IPC content, job satisfaction and cooperative behaviors altogether.

Specifically, the hypotheses of the study were:

$\mathrm{H}_{1}$ : Organizational ideological obligations positively influence workers' ideological obligations.

$\mathrm{H}_{1 \mathrm{a}}$ : Workers' ideological obligations mediate the positive effect of organizational ideological obligations on organizational respect.

$\mathrm{H}_{2}$ : Organizational ideological obligations have a positive direct influence on organizational respect.

$\mathrm{H}_{3}$ : Organizational respect enhances job satisfaction.

$\mathrm{H}_{4}$ : Job satisfaction has a negative influence on workers' turnover intentions.

$\mathrm{H}_{5}$ : Job satisfaction boosts organizational citizenship behaviors directed to the organization

These hypotheses conform the hypothetical model represented in Figure 1. Noteworthy, hypotheses 1 and 2 have never been tested in any type of enterprise. Further, hypotheses 3, 4 and 5, as proposed in Figure 1, have never been validated in organizations created by CSR programs. Thus, testing the entire hypothetical model (see Figure 1) contributes not only to CSR literature, but also to psychological studies interested in the mechanisms through which socially oriented ideologies positively influence cooperative behaviors directed to the organization.

\section{Figure 1. Theoretical model}

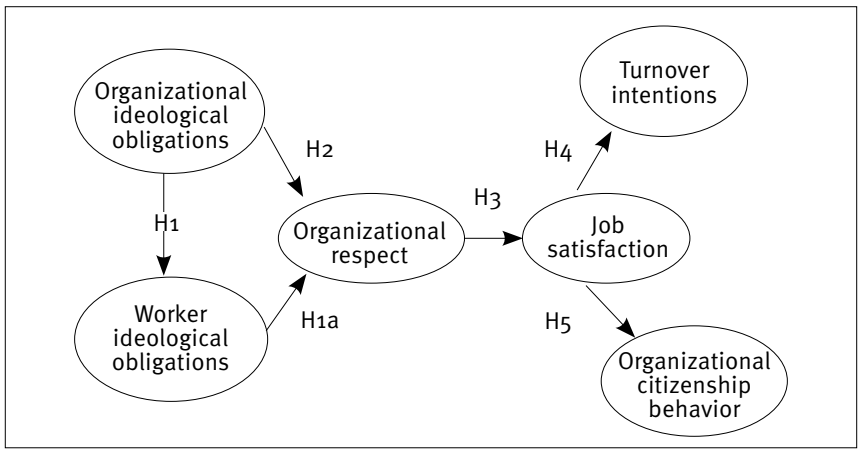

\section{METHOD}

A back-translated questionnaire (Schaffer \& Riordan, 2003) was administrated to 290 paid employees of a Colombian hybrid organization. The participants responded voluntarily to the survey. This enterprise was created by a for-profit organization through a CSR program. For almost 28 years, the enterprise has functioned independently in the regional textile sector and provided employment to local disadvantaged women. The survey obtained a response rate of $80 \%$. At the end, 218 questionnaires were usable for subsequent analyses. Questionnaires with missing data were not included for the statistical analysis. Nearly, 93\% of the participants were women whereas the mean tenure was 13 years. The average age of the respondents was 34 years.

\section{Measures}

The questionnaire was previously presented to the administrative staff. The procedure was adopted in order to guarantee the fitness of the questionnaire to the organizational context. Bingham's (2005) measure was used to assess organizational and workers' ideological obligations (Vantilborgh et al., 2013). Two self-reported scales compose this measure. Each IPC scale is conformed by 7 items (Bingham, 2005). The first scale (IPCOO) evaluates the perception of workers regarding the organization's obligations with regard to the organizational social cause. The second scale (IPCWO) measures the perception of workers with regard to their ideological obligations. Like in all measures used in the survey, respondents used a 5 points Likert scale. While the IPCOO scale began with the header " $X$ is obligated to", the IPCWO was introduced by the statement "As a worker at XI feel I'm obligated to". Examples of the items of the scales are: "contribute to the stated cause" and "maintain a company culture that promotes our corporate principles".

Workers feelings of being respected by the organization were assessed through an adapted version of the Autonomous Respect Scale developed by Tyler and Blader (2002). Previous research has showed good reliability indices for this three-item measure; the scale obtained an $a=0.84$ in Boezeman and Ellemers's (2007) study and an $a=0.95$ index in Tyler and Blader's (2002) investigation. Sample items are: "I feel respected as an employee by $X$ and $X$ cares about my opinion as an employee".

Job satisfaction was measured using three items of The Michigan Organizational Assessment Questionnaire (Cammann, Fichman, Jenkins, \& Klesh, 1979). This measure has been widely used in organizational research. Examples of the items of this scale are: "All in all I am satisfied with my job" and "In general, I don't like my job”. 
Organizational citizenship behaviors directed to the organization were assessed with Lee and Allen's (2002) subscale. The subscale was introduced to the respondents by the following statement: "This section of the questionnaire regards the way you act towards your organization". Sample items are: "Attend functions that are not required but that help the organizational image" and "defend the organization when other employees criticize it".

Finally, turnover intentions were measured with the twoitem scale developed by Bentein, Vandenberg, Vandenberghe and Stinglhamber (2005). The heading "Regarding my future... preceded the items of this scale". Examples of these items are: "I often think about quitting this organization" and "I intend to search for a position with another employer within the next year".

\section{Analysis}

Smart PLS (version 2.0 beta) statistical software was used for data analysis (Ringle, Wende, \& Will, 2005). The Partial Least Squares Structural Equation modeling method (PLSSEM) was chosen to test the theoretical model. As covariance-based SEM (CBSEM), PLSSEM consents the analyses of different complex relationships between latent variables (LVs) belonging to the same model. Furthermore, like CBSEM, PLSSEM provides statistics on the psychometric properties of the measurement instruments. Summarizing, PLSSEM produces results to evaluate the structural and measurement models included in theoretical models with LVs. Conversely, compared with CBSEM, PLSSEM is less restrictive in terms of sample-size (Haenlein \& Kaplan, 2004). Moreover, PLSSEM can be used in both exploratory and confirmatory studies. As is the case for this exploratory study, PLSSEM is particularly suitable to test, through the usage of new measures, theoretical models including new relationships between constructs (Chin, 2010).

The PLSSEM methodology is a two-step approach. The first step consists in assessing the measurement model. The evaluation of the PLSSEM measurement model implies an analysis of the construct validity for all LVs. To conclude about the convergent validity of the LVs, the researcher has to weigh the average variance extracted (AVE) and the communality of the observed variables (OVs). The composite reliability (CR) index and Cronbach's Alpha (a) are habitually used to conclude on the reliability of the scales. In order to validate the measurement model, its statistics need to overcome the following critical values: AVE > 0.5; communalities > 0.5; CR > 0.7; $a>0.6$ (Chin, 2010; Götz, Liehr-Gobbers, \& Krafft, 2010).

The OVs' cross-loadings and the AVE test provide evidence on the divergent validity of the LVs. In PLSSEM, OVs loadings on the expected LVs need to be up 0.7 (Hulland, 1999). Noteworthy,
PLSSEM algorithm tends to increase OVs' loadings to favor the analysis of the explained variance $\left(R^{2}\right)$ of the endogenous LVs. This is the reason for the presence in PLSSEM measurement models of OVs cross-loadings exceeding the regular value of $>0.4$. However, the OVs cross-loadings cannot overcome the loading on the theoretical LV (Chin, 2010; Götz et al., 2010). The AVE test consists in comparing the square root of AVE with the construct correlations. When this value exceeds each pair of correlations, the LV's divergent validity can be concluded (Fornell \& Larcker, 1981).

The second phase of the PLSSEM methodology is the evaluation of the PLS structural model. The PLSSEM structural model is examined by weighting the endogenous LVs' $R^{2}$, the standardized regression coefficients $(\beta)$, the size effects of the predictors $\left(f^{2}\right)$, the statistical significance of each of the equations composing the model and the Stone-Geisser test $\left(\mathrm{Q}^{2}\right)$. Two $\mathrm{Q}^{2}$ statistics are used to evaluate the predictive validity of the PLS structural model: the cross-validated communality $\left(\mathrm{H}^{2}\right)$ for all LVs and the cross-validated redundancy $\left(\mathrm{F}^{2}\right)$ for the endogenous LVs. These two indexes refer to the PLSSEM model capability to predict the OVs (Götz et al., 2010). Rules of thumb for the statistics to assess the PLSSEM structural model are: $\mathrm{R}^{2}$ values of $0.67,0.33$, and 0.19 are described as substantial, moderate and weak (Chin, 1998). $\mathrm{f}^{2}$ values of $0.02,0.15$ and 0.35 indicate small, medium, and large effects (Cohen, 1988). $\mathrm{H}^{2}$ and $\mathrm{F}^{2}$ values exceeding zero support the predictive validity for the PLSSEM structural model (Chin, 2010; Götz et al., 2010). The overall predictive capability of the PLSSEM structural model can be confirmed through the evaluation of the global criterion of goodness (GoF index) (Tenenhaus, Amato, \& Vinzi, 2004). GoF values of $0.10,0.25$ and 0.36 correspond to low, medium and high model predictive capability (Wetzels, Odekerken-Schröder, \& Oppen, 2009).

Since PLSSEM analyses do not provide goodness of fit indexes allowing comparisons between competitive models. An alternative procedure was adopted to this end. An additional path was added to the original model in order to test another PLSSEM model. To decide between the two models, both the significance and the effects on LVs' $R^{2}$ of the additional path were weighted. At last, the significance of some of the indirect effects of the theoretical model was assessed using bias-corrected bootstrap confidence intervals (Chin, 2010). First, the coefficients corresponding to the direct paths composing each indirect effect were calculated using bootstrap resampling. Then, the researchers followed the product-of-coefficients approach illustrated by Preacher and Hayes (2008). The product of the bootstrapped coefficients was calculated. Finally, 99\% bias-corrected bootstrap confidence intervals were extracted with SPSS statistical software (version 20). Following this approach, the significance of the indirect effects is supported by the absence of zero in the confidence intervals. 
Finally, we controlled for demographic variables and common method variance. This procedure was adopted in order to test if the inclusion of such variables affected the significance of the paths composing the hypothetical model. Given that all measures were self-reported we decided to test for common method variance. Common method variance is the "variance that is attributable to the measurement method rather than to the constructs the measures represent" (Podsakoff, Mackenzie, Lee, \& Podsakoff, 2003. p. 879). The common method factor (CMF) procedure has been recently adapted to the PLS SEM framework (Rönkkö \& Ylitalo, 2011). The procedure consists in introducing a CMF within the PLS structural model. The CMF, composed by additional items poorly correlated with the observable variables under study, is related to all the latent endogenous variables. In PLS SEM, if the paths composing the baseline model become non-significant with the introduction of the CMF there is evidence of data common method variance issues (Rönkkö \& Ylitalo, 2011).

\section{RESULTS}

All findings regarding the PLS measurement model were satisfactory. According to the results of the analyses, construct validity can be concluded for all the LV's. In particular, all OV's adequately loaded on the corresponding construct $(>0.7)$ and there were no cross-loadings higher than the cut-off value for PLS SEM models $(\geq 0.7)$ (see Table 1).

Table 1. Cross-loadings - PLS measurement model

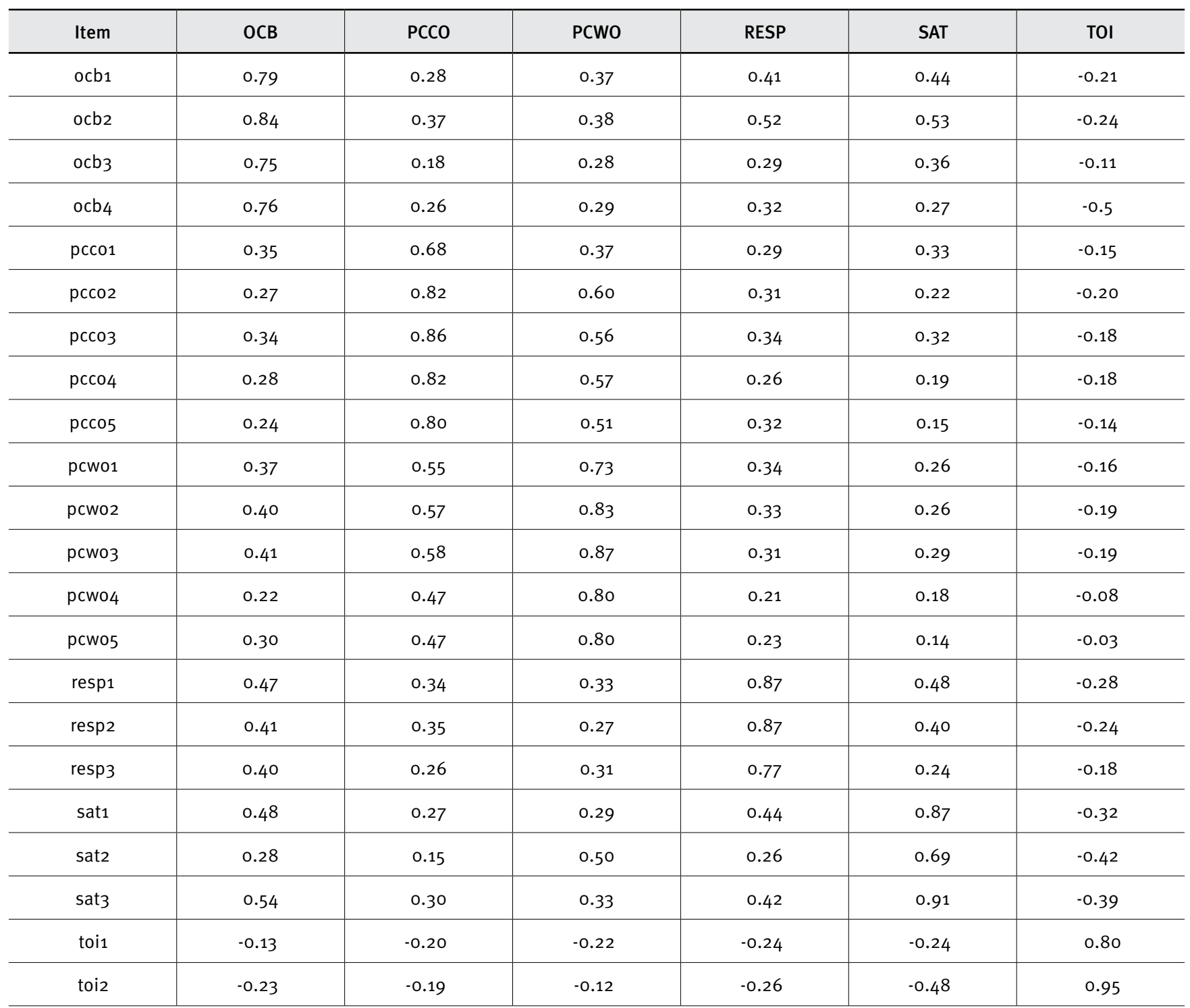


Further support for divergent validity of all LVs was found in subsequent analyses. The divergence between the constructs was confirmed by the AVE test (see Table 2). Noteworthy, the values of the AVE test for each construct exceeded all paired correlations. Moreover, acceptable values in all reliability coefficients were found for all LVs (see Table 2). In all cases, a matched the corresponding rule of thumb (> o.6). Likewise, the CRs of all LVs overcame the cutoff value (>0.8). As regards the convergent validity of the constructs, all values were satisfactory (AVE > 0.5). Moreover, as displayed in Table 2, each communality index overcame the critical value (>0.5).

\section{Table 2. PLS model LVs correlations, reliability and construct validity indexes}

\begin{tabular}{l|c|c|c|c|c|c|c|c|c}
\hline & $\mathbf{1}$ & $\mathbf{2}$ & $\mathbf{3}$ & $\mathbf{4}$ & $\mathbf{5}$ & $\mathbf{6}$ & $\mathrm{CRa}$ & $\mathrm{ab}$ & AVEc \\
\hline OCB & $\mathbf{0 . 7 8 *}$ & & & & & & 0.86 & 0.80 & 0.61 \\
\hline PCCO & 0.37 & $\mathbf{0 . 8 0}$ & & & & & 0.90 & 0.86 & 0.64 \\
\hline PCWO & 0.43 & 0.66 & $\mathbf{0 . 8 1}$ & & & & 0.90 & 0.87 & 0.65 \\
\hline RESP & 0.51 & 0.38 & 0.36 & $\mathbf{0 . 8 4}$ & & & 0.87 & 0.79 & 0.70 \\
\hline SAT & 0.54 & 0.30 & 0.29 & 0.46 & $\mathbf{0 . 8 3}$ & & 0.87 & 0.77 & 0.69 \\
\hline TOI & -0.21 & -0.21 & -0.17 & -0.28 & -0.45 & $\mathbf{0 . 8 8}$ & 0.87 & 0.73 & 0.77 \\
\hline
\end{tabular}

Note: $\mathrm{n}=218$

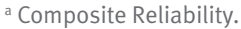

${ }^{b}$ Cronbach's Alfa.

Average Variance Extracted (AVE).

AVE Test (Fornell and Larcker, 1981) = Squared root of AVE.

The results for the PLS structural model were satisfactory. All paths were significant when the effects of demographic variables and membership were controlled. Besides, no evidence of common method variance was found after introducing the CMF in the baseline model. Globally, the values obtained by the PLS structural model supported the six hypotheses of the study (see Table 3). In particular, aside from the explained variance of Resp, all $\mathrm{R}^{2}$ values were suitable. Furthermore, the $\mathrm{H}^{2}$ and $\mathrm{F}^{2}$ results ( $>0$ ) confirmed the high predictive validity indicated by the GoF index. Thus, in general the statistical analysis supports all the hypotheses of the study. However, after post-hoc analyses, an additional path was added to the model.

\section{Table 3. PLS model LVs explained variance,} communalities and redundancies

\begin{tabular}{l|c|c|c|c|c}
\hline Variable & $\mathbf{R}^{2}$ & Communality & $\mathbf{H}^{2}$ & Redundancy & $\mathbf{f}^{\mathbf{2}}$ \\
\hline PCCO & & 0.64 & 0.64 & & \\
\hline PCWO & 0.44 & 0.65 & 0.65 & 0.28 & 0.27 \\
\hline RESP & 0.17 & 0.70 & 0.70 & 0.09 & 0.10 \\
\hline SAT & 0.21 & 0.69 & 0.69 & 0.15 & 0.13 \\
\hline TOI & 0.20 & 0.77 & 0.77 & 0.14 & 0.13 \\
\hline Average & 0.28 & 0.68 & & & \\
\hline GoF* & 0.43 & & & & \\
\hline
\end{tabular}

Note: $n=2580,{ }^{\star}$ Global criterion of goodness of fit.
Table 4 shows specific results for the post-hoc added path and for each of the six hypotheses constituting the theoretical model. As reflected by the t-values, aside from the regression coefficient from PCWO to RESP, the relationships among the variables under study were significant at the $p<0.01$ level. Notwithstanding the lower power and significance of the relationship between PCWO and RESP, the presence of PCWO within the PLS model was guaranteed by the analysis of the indirect effect that PCCO exerts on RESP; zero was absent in zero in the $99 \%$ bias-corrected bootstrap confidence interval (0.12-0.13).

Table 4. PLS structural model

\begin{tabular}{|c|c|c|c|c|}
\hline Paths & $\beta$ & t-value & $f^{2}$ & Ratings \\
\hline PCCO …; PCWO & 0.66 & $150.46^{\star}$ & & \\
\hline PCCO …. & 0.25 & $20.78^{\star}$ & 0.04 & Small to medium \\
\hline PCWO …* RESP & 0.19 & $20.29^{\star \star}$ & 0.02 & Small to medium \\
\hline RESP …ㄱ SAT & 0.46 & $60.07^{\star}$ & 0.13 & Small to medium \\
\hline RESP …. $\geqslant$ OCB & 0.34 & $40.37^{\star}$ & 0.14 & Small to medium \\
\hline SAT $\cdots . . . *$ TOI & -0.45 & $70.18^{\star}$ & 0.15 & Medium to large \\
\hline SAT $\cdots . . . \%$ OCB & 0.38 & $50.36^{\star}$ & 0.18 & Medium to large \\
\hline
\end{tabular}

Note: $\mathrm{n}=218$. Bootstrapping 1000 samples.

$\beta=$ Standardized coefficients

$\mathrm{f}^{2}=$ Effect size

${ }^{\star} p<0.01 ;{ }^{* \star} p<0.05$

The results regarding other paths of the PLS structural model are interesting as well. Conversely to prior research, no direct relationship was found between RESP and TOI. In their Tyler and Blader (2002) research, by means of CBSEM and the use of the parceling technique, they found that, in a number of forprofit organizations, autonomous respect significantly predicted turnover intentions. Again, differences in method and distinct organizational contexts could explain these differences in results. Still, according to the results presented here, there is a relationship between RESP and TOI, but this relationship appears to be indirect. In fact, the significance of this indirect effect was confirmed by the absence of zero in the $99 \%$ bias-corrected bootstrap confidence interval (-0.21 -0.20). Put differently, further statistical analysis confirmed the hypothesis that SAT mediated the indirect influence of RESP on TOI. With regard to the path between SAT and TOI, the results of this study support the findings of a study recently conducted by Ohana and Meyer (2010). These authors found a similar effect size for this relationship. They used the PLS SEM to analyze data collected from hybrid organizations. On the other hand, several studies have demonstrated the relationship between satisfaction and the other outcome variable of the study (i.e. OCB directed to the organization; Organ, 1988). According to Organ (1988), employees are likely to engage in OCB when they feel they aretreated fairly. More generally, the satisfactory 
results of the whole PLS SEM model are congruent with Organ's argument. Specifically, the model indicates that when the organization is truthful to its social cause, the employees will feel more attached to the organizational social goal. Moreover, as a result of the support of the commonly valued social organizational cause, employees will feel respected by the organization, more satisfied, more engaged to OCB towards the organization and less tempted to leave the organization.

\section{DISCUSSION}

This study aimed at providing further empirical evidence of the impact of principles within for independent hybrid organizations created through CSR programs. Overall, the hypotheses of the study proposed that the engagement of these organizations with respect to their social mission, as perceived by paid employees, had a positive and significant effect on the employee-employment exchange, and subsequently, on attitudes and behaviors towards the organization. The results presented above suggest that, in this type of organization, organizational ideological obligations with regard to the social cause favor paid employees ideological obligations, which in turn boost positive attitudinal and behavioral outcomes. Specifically, the findings of the study indicate that, in Colombian hybrid organizations, organizational ideological obligations predict paid employees ideological obligations with regard to the organizational social cause. Hence, empirical evidence is provided on the existence of an ideological profile among independent hybrid organizations resulting from CSR programs. That is to say that, arguably, people working in this type of organization care about the social impact of both the organizational activities and their own job. Furthermore, by introducing mediators like respect and job satisfaction, these findings enlarge the empirical evidence on the psychological mechanisms explaining some effects of ideology on positive organizational behaviors and attitudes (i.e. OCB and turnover intentions). Using second-generation statistical analysis and the inclusion of further psychological variables, this paper provides greater empirical support to economic analyses that situate the social cause of the organization as the main psychological drive within hybrid organizations (Borzaga \& Tortia, 2006).

\section{Practical implications}

The results presented above have several practical implications. Some scholars have asserted that hybrid organizations are facing more and more recruitment and retention problems (Tortia, 2009). In addition, literature on hybrid organizations indicates that considering workers' ideological orientation is fundamental to manage these human resources issues adequately (Ohana \& Meyer, 2010). Moreover, research has shown that perceptions of procedural fairness are correlated with intentions to remain with the organization (Tortia, 2009). This paper continued in this line of research by indicating that IPC has a negative, indirect effect on turnover intentions within hybrid organizations. The results presented here suggest that socially oriented principles are necessary when managing organizations that emerge from CSR programs. In order to enhance more durable employment relationships in these organizations, practitioners need to be aware of the importance given by the employees to the social organizational cause. The perceived alignment of hybrid organizations with regard to their social cause seems to be a powerful antecedent of worker social identification with the organization. The findings presented in this paper suggest that positive behaviors directed to the organization are likely to occur when workers in these organizations perceive that the organizational practices are congruent with the social cause. Thus, in order to reduce social-oriented enterprise withdrawal issues, managers of organizations resulting from CSR programs need to be aware that employees assess the extent to which organizational strategy, goals and practices are aligned with the organizational social cause. Hence, effective strategies should to be put in place to communicate the social impact of organizational activities to the employees. In the same vein, more emphasis must be made on the fact that working in this type of organization also implies following a social cause. According to our findings, these strategies could be useful to cope with the recruitment and retention issues these organizations have to face.

\section{Limitations and future research}

No other PC dimensions were investigated. As a result, no conclusions were drawn on the relative importance of ideological contents for the development of the employer-employee relationship within hybrid organizations. Future studies could contrast in this organizational setting perceived workers transactional and ideological obligations and specify the outcomes of each PC form. This would give managers of hybrid organizations more proximal clues about how to provide the adequate incentive mixes needed to avoid typical retention issues (Borzaga \& Tortia, 2006; Imperatori \& Ruta, 2006; Tortia, 2009).

A cross-sectional design was followed to inquire on the organizational outcomes of ideological obligations within social oriented enterprises created through CSR programs. However, no causal relationships can be demonstrated based on this research approach. The exploratory results and conclusions discussed 
before are thus presented as proposals for future studies using more accurate research designs. For instance, CB-based latent growth models would help to inquire on the consequences of fulfillment or break of ideological obligations within hybrid social oriented enterprises. Finally, although a CMF was introduced in the theoretical model to control common method variance, further research may consider other types of measures to assess organizational ideological obligations.

\section{REFERENCES}

Amin, A. (2009). Extraordinarily ordinary: Working in the social economy. SocialEnterpriseJournal,5(1),30-49. doi:10.1108/17508610910956390

Austin, J. E., Stevenson, H., \& Wei-Skillern, J. (2006). Social and commercial entrepreneurship: Same, different, or both? Entrepreneurship Theory \& Practice, 30(1), 1-22. doi:10.1111/j.1540-6520.2006.00107.x

Bal, P., \& Vink, R. (2011). Ideological currency in psychological contracts: The role of team relationships in a reciprocity perspective. The International Journal of Human Resource Management, 22 (13), 2794-2817. doi :10.1080/09585192.2011.560869

Bentein, K., Vandenberg, R., Vandenberghe, C., \& Stinglhamber, F. (2005). The role of change in the relationship between commitment and turnover: A latent growth modeling approach. Journal of Applied Psychology, 9o(3), 468-482. doi:10.1037/0021-9010.90.3.468

Bhattacharya, C. B., Sen, S. \& Korschun, D. (2008). Using corporate social responsibility to win the war for talent. Sloan Management Review, 49(2), 37-44.

Bingham, J. B. (2005). Multiple obligations: Distinguishing the dimensionality and confirming the role of ideology within the psychological contract framework. Unpublished doctoral dissertation, Texas A\&M University, Galveston.

Boezeman, E. J., \& Ellemers, N. (2007). Volunteering for charity: Pride, respect, and the commitment of volunteers. Journal of Applied Psychology, 92(3), 771-785. doi:10.1037/0021-9010.92.3.771

Borzaga, C., \& Bacchiega, A. (2001). Social enterprises as incentive structures: An economic analysis. In C. Borzaga \& J. Defourny, (Eds.) The emergence of social enterprise (p. 273). Psychology Press.

Borzaga. C., \& Tortia, E. (2006). Worker motivations, job satisfaction, and loyalty in public and nonprofit social services. Nonprofit and Voluntary Sector Quarterly, 35(2), 225-248. doi:10.1177/0899764006287207

Cammann, C., Fichman, M., Jenkins, D., \& Klesh, J. (1979). The Michigan Organizational Assessment Questionaire. Unpublished manuscript, Anne Arbor, University of Michigan.

Chin, W. W. (1998). The partial least squares approach for structural equation modeling. In G. A. Marcoulides (Ed.). Modern methods for business research (pp. 295-236). London: Lawrence Erlbaum Associates.

Chin, W. W. (2010). How to write up and report PLS analyses. In V. E. Vinzi, W. W. Chin, J. Henseler, \& H. Wang (Eds.). Handbook of partial least squares (pp. 655-690). Berlin: Springer-Verlag.

Chong, M. (2009). Employee participation in CSR and corporate identity: Insights from a disaster-response program in the Asia-Pacific. Corporate Reputation Review, 12(2), 106-119. doi:10.1057/crr.2009.8
Cohen, J. (1988). Statistical power analysis for the behavioral sciences. Hillsdale, NJ: Lawrence Erlbaum Associates.

Dalal, R. (2005). A meta-analysis of the relationship between organizational citizenship behavior and counterproductive work behavior. Journal of Applied Psychology, 9o(6), 1241-1255. doi:10.1037/00219010.90.6.1241

Doherty, B., Foster, G., Mason, C., Meehan, K., Rotheroe, N., \& Royce, M. (2009). Management for social enterprise. London: Sage.

Fornell, C., \& Larcker, D. F. (1981). Evaluating structural equation models with unobservable variables and measurent error. Journal of Marketing Research, 18(1), 39-50.

Götz, O., Liehr-Gobbers, K., \& Krafft, M. (2010) Evaluation of structural equation models using the partial least squares (PLS) approach. In V. E. Vinzi, W. W. Chin, J. Henseler, \& H. Wang (Eds.). Handbook of partial least squares (pp. 691-711). Berlin: Springer-Verlag.

Greening, D. W., \& Turban, D. B. (2000). Corporate social performance as a competitive advantage in attracting a quality workforce. Business and Society, 39(3), 254-280. doi:10.1177/000765030003900302

Haenlein, M. A. \& Kaplan, A. M. (2004). A beginner's guide to partial least squares analysis. Understanding Statistics, 3(4), 283-297. doi:10.1207/S15328031us0304_4

Hulland, J. (1999). Use of partial least squares (PLS) in strategic management research: A review of four recent studies. Strategic Management Journal, 20(2), 195-204. doi:10.1002/(SICl)1097-0266(199902)20:2«1 95::AID-SMJ13'3.0.CO;2-7

Imperatori, B., \& Ruta, D. (2006). Organizing a social enterprise. In F. Perrini (Ed.). The new social entrepreneurship: What awaits social entrepreneurial ventures? (pp. 105-121). Cheltenham, UK: Edward Elgar Publishing.

Jamali, D., \& Mirshak, R. (2007). Corporate social responsibility (CSR): Theory and practice in a developing country context. Journal of Business Ethics, 72(3), 243-262. doi:10.1007/s10551-006-9168-4

Lee, K., \& Allen, N. J. (2002). Organizational citizenship behavior and workplace deviance: The role of affect and cognitions. Journal of Applied Psychology, 87(1), 131-142. doi:10.1037/0021-9010.87.1.131

Levi, Y., \& Davis, P. (2008). Cooperatives as the "enfants terribles" of economics: Some implications for the social economy. The Journal of Socio-Economics, 37(6), 2178-2188. doi:10.1016/j.socec.2008.06.003

McNeely, B. L., \& Meglino, B. M. (1994). The role of dispositional and situational antecedents in prosocial organizational behavior: An examination of the intended beneficiaries of prosocial behavior. Journal of Applied Psychology, 79(6), 836-844. doi:10.1037/0021-9010.79.6.836

Michailides, T. P., \& Lipsett, M. G. (2013). Surveying employee attitudes on corporate social responsibility at the frontline level of an energy transportation company. Corporate Social Responsibility and Environmental Management, 20(5), 296-320. doi:10.1002/csr.1291

Mosca, M., Musella, M., \& Pastore, F. (2007). Relational goods, monitoring and non-pecuniary compensations in the nonprofit sector: The case of the Italian social services. Annals of Public and Cooperative Economics, 78(1), 57-86. doi:10.1111/j.1467-8292.2007.00327.x

Ohana, M., \& Meyer, M. (2010). Should I stay or should I go now? Investigating the intention to quit of the permanent staff in social enterprises. European Management Journal, 28(6), 441-454. doi:10.1016/j. emj.2010.06.007

Organ, D. W. (1988). Organizational citizenship behavior: The good soldier syndrome. New York: Lexington Books. 
Organ, D. W. (1997). Organizational citizenship behavior: It's construct clean-up time. Human Performance, 10(2), 85-97. doi:10.1207/ s15327043hup1002_2

Podsakoff, P. M., Mackenzie, S. B., Lee, J. Y., \& Podsakoff, N. P. (2003). Common method biases in behavioral research: A critical review of the literature and recommended remedies. Journal of Applied Psychology, 88(5), 879-903. doi:10.1037/0021-9010.88.5.879

Preacher, K. J., \& Hayes, A. F. (2008). Asymptotic and resampling strategies for assessing and comparing indirect effects in multiple mediator models. Behavior Research Methods, 40(3), 879-891. doi: 10.3758/ BRM.40.3.879

Ringle, C. M., Wende, S., \& Will, A. (2005). SmartPLS. Hamburg: SmartPLS. Rönkkö, M., \& Ylitalo, J. (2011, December 5). PLS marker variable approach to diagnosing and controlling for method variance. Proceedings of ICIS, Shanghai, China. Retrieved from http://aisel.aisnet.org/ icis2011/proceedings/researchmethods/8

Rousseau, D. M. (1989). Psychological and implied contracts in organizations. Employee Responsibilities and Rights Journal, 2(2), 121-139.

Rousseau, D. M. (1995). Psychological contracts in organizations: Understanding written and unwritten agreements. Thousand Oaks, CA: Sage.

Rousseau, D. M. (2001). Schema, promise and mutuality: The building blocks of the psychological contract. Journal of occupational and Organizational Psychology, 74(4), 511-541. doi:10.1348/096317901167505

Schaffer, B. S., \& Riordan, C. M. (2003). A review of cross-cultural methodologies for organizational research: A best-practices approach. Organizational Research Methods, 6(2), 169-215. doi: 10.1177/1094428103251542

Smith, C. A., Organ, D. W., \& Near, J. P. (1983). Organizational citizenship behavior: Its nature and antecedents. Journal of Applied Psychology, $68(4), 653-663$.
Tenenhaus, M., Amato, S., \& Vinzi, V. E. (2004). A global goodness-offit index for PLS structural equation modeling. Proceedings of the SIS Scientific Meeting, Padova, Italy, CLEUP, 42.

Thompson, J. A., \& Bunderson, J. S. (2003). Violations of principle: Ideological currency in the psychological contract. Academy of Management Review, 28(4), 571-586.

Tortia, E. (2009). Perceived fairness and worker well-being in public, for-profit and nonprofit firms: Evidence from the Italian social service sector. In S. Destefanis, \& M. Mussella (Eds.). Paid and unpaid labour in the social economy (pp. 97-114). Heidelberg: Physica-Verlag HD.

Turnley, W. H., \& Feldman, D. C. (2000). Re-examining the effects of psychological contract violations: Unmet expectations and job dissatisfaction as mediators. Journal of Organizational Behavior, 21(1), 25-42. doi:10.1002/(SICI)1099-1379(200002)21:1く25::AID-JOB2〉3.0.CO;2-Z

Tyler, T. R., \& Blader, S. L. (2002). Autonomous vs. comparative status: Must we be better than others to feel good about ourselves? Organizational Behavior and Human Decision Processes, 89(1), 813-838. doi:10.1016/So749-5978(02)00031-6

Vantilborgh, T., Bidee, J., Pepermans, R., Willems, J., Huybrechts, G., \& Jegers, M. (2013). Effects of ideological and relational psychological contract breach and fulfilment on volunteers' work effort. European Journal of Work \& Organizational Psychology, 23(2), 217-230. doi:10. 1080/1359432X.2012.740170

Wetzels, M., Odekerken-Schröder, G., \& Oppen, C. Van. (2009). Using PLS path modeling for assessing hierarchical construct models: Guidelines and empirical illustration. MIS Quarterly, 33(1), 177-195.

Williams, L. J., \& Anderson, S. E. (1991). Job satisfaction and organizational commitment as predictors of organizational citizenship and in-role behaviors. Journal of Management, 17(3), 601-617. doi:10.1177/014920639101700305. 